\title{
Dissolved Nutrient Fluxes through a Sandy Estuarine Beachface (Cape Henlopen, Delaware, U.S.A.): Contributions from Fresh Groundwater Discharge, Seawater Recycling, and Diagenesis
}

\author{
Rebecca L. Hays • William J. Ullman
}

Published online: 16 April 2008

(C) Coastal and Estuarine Research Federation 2008

Erratum to: Estuaries and Coasts: J CERF,

Volume 30, Number 4, August, 2007

DOI: $10.1007 /$ BF02841967

Figure 7 is a duplicate of Figure 6 in the original article. The correct Figure 7 is as follows:

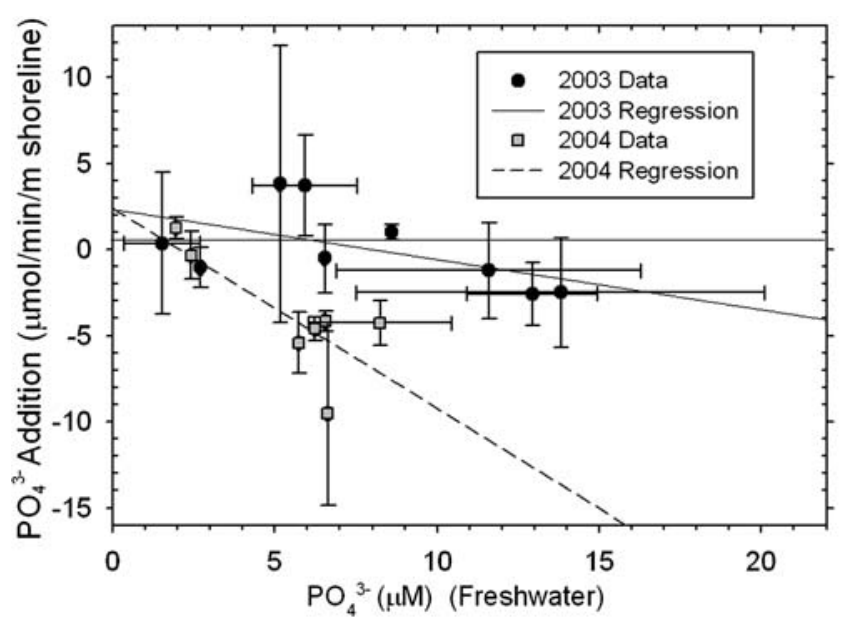

Fig. 7 Contrasting diagenetic behavior of phosphate $\left(\mathrm{PO}_{4}\right)$ before and after beach replenishment. Prior to replenishment in December 2003, the beachface had little or no effect on the $\mathrm{PO}_{4}$ fluxes to the adjacent estuary. Following replenishment, higher concentrations of $\mathrm{PO}_{4}$ in the upland groundwater (a proxy for concentrations in the beachface aquifer) are associated with higher rates of $\mathrm{PO}_{4}$ consumption in the beachface. This may be due to the addition of iron with the new sand and increased adsorption of $\mathrm{PO}_{4}$ onto iron oxyhydroxide surfaces after replenishment

The online version of the original article can be found at http://dx.doi. org/10.1007/BF02841967.

R. L. Hays $(\bowtie) \cdot$ W. J. Ullman

College of Marine and Earth Studies, University of Delaware,

700 Pilottown Road,

Lewes, DE 19958-1298, USA

e-mail: rhays@udel.edu 